\title{
Enterogastrone-like Effect of Peptide YY Is Vagally Mediated in the Dog
}

\author{
T. N. Pappas, H. T. Debas, and I. L. Taylor \\ Sepulveda Veteran's Administration Medical Center, Sepulveda, California 91343; The Center for Ulcer Research and Education, \\ Wadsworth Veteran's Administration Hospital, Los Angeles, California 90073; and University of California \\ at Los Angeles School of Medicine, Los Angeles, California 90024
}

\begin{abstract}
Intraluminal fat inhibits gastric secretion through as yet undetermined mechanisms which involve release of one or more hormonal enterogastrones. As intraluminal fat releases Peptide YY (PYY) in amounts sufficient to inhibit meal-stimulated acid secretion, this ileo-colonic peptide exhibits the characteristics required of an enterogastrone. The present study seeks to determine the mechanism by which PYY inhibits acid secretion by examining the effects of PYY on gastric acid stimulated by pentagastrin, histamine, and bethanechol. In addition, effects of PYY on the acid response to sham feeding and distention of a denervated gastric pouch were examined. A dose of PYY (400 $\mathrm{pmol} \cdot \mathrm{kg}^{-1} \cdot \mathrm{h}^{-1}$ ) was employed that reproduced blood levels observed after intestinal perfusion with oleic acid and inhibited the acid secretory response to an intragastric meal by $35 \pm 6 \%$. This same dose of PYY maximally inhibited histamine- and pentagastrin-stimulated acid secretion by $28 \pm 7 \%(P<0.05)$, and $17 \pm 4 \%(P<0.05)$, respectively. Although PYY had no effect on bethanechol-stimulated secretion it markedly inhibited the secretory response to sham feeding, maximally reducing secretion by $90 \pm 4 \%(P<0.01)$. We speculate that PYY acts by inhibiting acetylcholine release from vagal nerve fibers rather than by inhibiting acetylcholine's action on the parietal cell. The demonstration that PYY virtually abolishes cephalic phase acid secretion while having little if any effect on the response to exogenous secretogogues gives PYY unique characteristics among the known hormonal inhibitors of gastric secretion.
\end{abstract}

\section{Introduction}

In 1886, Ewald and Boas (1) noted that addition of olive oil to a test meal of gruel depressed acid secretion in human subjects. Workers in Pavlov's laboratory demonstrated that this phenomenon could only be demonstrated if fat was allowed to pass beyond the stomach (2). Subsequent studies by Lim and coworkers $(3,4)$ demonstrated that this response was at least in part hormonally mediated and could be reproduced by the injection of crude mucosal extracts of both the small and large intestine. Despite their observation that colonic extracts were as potent as jejunal extracts, the search for enterogastrones has largely centered on the mucosa of the small intestine. However, increased interest in the colon as an endocrine organ has been engendered by studies (5-7) that demonstrate inhibition of gastric

Address reprint requests to Dr. Taylor, Division of Gastroenterology (111 G), Sepulveda Veteran's Administration Medical Center, 16111 Plummer St., Sepulveda, CA 91343.

Received for publication 20 February 1985 and in revised form 2 August 1985.

The Journal of Clinical Investigation, Inc.

Volume 77, January 1986, 49-53 secretion after perfusion of the colon with a variety of nutrients, including fat.

Recently, a peptide isolated $(8,9)$ from porcine intestinal mucosa (Peptide YY) has been demonstrated to inhibit mealstimulated acid secretion (10). Peptide YY (PYY) ${ }^{1}$ is present in highest concentrations in the mucosa of the ileum and colon where it is localized to endocrine-like cells (11). The demonstration that PYY is released into the circulation after ingestion of a meal (12) suggests a hormonal action for this peptide. A role for PYY as an enterogastrone is supported by the demonstration that blood levels observed after intestinal perfusion with oleic acid are capable of inhibiting meal-stimulated acid secretion (10). To examine the mechanism(s) by which PYY inhibits acid secretion, we studied the effects of exogenously infused synthetic PYY on gastric acid stimulated by pentagastrin, histamine, and bethanechol. A dose of PYY $\left(400 \mathrm{pmol} \cdot \mathrm{kg}^{-1} \cdot \mathrm{h}^{-1}\right)$ was chosen based on the prior demonstration that it reproduced blood levels observed after intestinal perfusion with oleic acid and significantly inhibited meal-stimulated acid secretion (10). In addition, we examined the effects of this dose of PYY on the acid secretory responses to both sham feeding and distention of a denervated gastric pouch. Finally, we tested the effects of PYY on mealstimulated gastrin release to determine if PYY exerts its inhibitory effect on acid secretion through inhibition of gastrin release.

\section{Methods}

Animals. A total of thirteen dogs were prepared variously with gastric fistula, esophageal fistula, or Heidenhain pouches using previously published methods $(10,13,14)$. The esophageal fistula was created in a twostage operation mobilizing the esophagus into a skin tunnel at the neck. The Heidenhain pouches were vagally denervated and created as a 30 $\mathrm{ml}$ pouch from the greater fundic curvature. Gregory cannulas drained the pouch to the surface of the anterior abdominal wall. Dogs were allowed several weeks to recover before study. During this time they were maintained on dog chow (Ralston Purina Co., Chow Div., St. Louis, MO) and then deprived of food, but not water, for $18 \mathrm{~h}$ before each study.

Effect of PYY on meal-stimulated acid secretion and gastrin release. Four gastric fistula dogs were infused with either intravenous saline or PYY $\left(400 \mathrm{pmol} \cdot \mathrm{kg}^{-1} \cdot \mathrm{h}^{-1}\right) 1 \mathrm{~h}$ before and $1 \mathrm{~h}$ after the intragastric instillation of a $300-\mathrm{ml}, 15 \%$ liver extract meal. The acid response to this meal was monitored by intragastric titration using $0.2 \mathrm{~N} \mathrm{NaOH}$ to maintain a constant intraluminal pH of 5.5 (15). In separate studies blood samples were drawn before and 30 and $60 \mathrm{~min}$ after intragastric instillation of the liver-extract meal during infusion of the saline carrier or $400 \mathrm{pmol} \cdot \mathrm{kg}^{-1} \cdot \mathrm{h}^{-1} \mathrm{PYY}$. Bloods were drawn into calcium oxalate tubes containing $500 \mathrm{U} / \mathrm{ml}$ trasylol. Plasma samples were assayed for gastrin (16) and PYY (12) using published methods.

Effect of PYY on sham feeding-stimulated acid secretion. Four esophageal fistula dogs were infused with either saline or PYY (400 $\mathrm{pmol} \cdot \mathrm{kg}^{-1} \cdot \mathrm{h}^{-1}$ ) $45 \mathrm{~min}$ before and during the hour after initiation of sham feeding. The dogs were allowed to sham feed $1,000 \mathrm{ml}$ of blenderized

1. Abbreviations used in this paper: PP, pancreatic polypeptide; PYY, Peptide YY. 
food for $15 \mathrm{~min}$ ad lib. Gastric secretion was collected continuously by gravity from the gastric fistula and divided into 15 -min intervals. Acid output was calculated by multiplying the volume by the concentration of acid determined by titration with $0.2 \mathrm{~N} \mathrm{NaOH}$ to $\mathrm{pH}$ 7.0.

Effect of PYY on histamine-, pentagastrin-, and bethanechol-stimulated acid secretion. Five gastric fistula dogs received either saline or PYY $\left(400 \mathrm{pmol} \cdot \mathrm{kg}^{-1} \cdot \mathrm{h}^{-1}\right)$ intravenously $15 \mathrm{~min}$ before, and continuously during dose responses to histamine $(10,20,40,80$, and $160 \mu \mathrm{g} / \mathrm{kg}$ per h), pentagastrin $(0.5,1,2,4$, and $8 \mu \mathrm{g} / \mathrm{kg}$ per h), and bethanechol $(12.5,25,50$, and $100 \mu \mathrm{g} / \mathrm{kg}$ per $\mathrm{h})$. They received each dose of gastric secretogogue for $45 \mathrm{~min}$ and gastric secretions were collected at 15 -min intervals. Dose-response curves were constructed by taking the average secretory rate observed during the last two 15 -min periods for each dose and plotting this response in millimoles $\mathrm{HCl} / 15$ min against dose-infused.

Effect of PYY on the acid response to Heidenhain pouch distention. Four dogs with Heidenhain pouches had saline or PYY $(400$ $\mathrm{pmol} \cdot \mathrm{kg}^{-1} \cdot \mathrm{h}^{-1}$ ) infused $15 \mathrm{~min}$ before and during distension of the Heidenhain pouch. Pouch distention was accomplished with $50 \mathrm{ml}$ of $0.9 \%$ saline using a barostat to maintain constant intraluminal pressure. The barostat was successively raised vertically every $30 \mathrm{~min}$ to create pouch distentions equal to 5,10 , and $20 \mathrm{~cm}$ of water pressure. The acid response to distention was determined by measuring the total volume in the barostat at the end of the 30-min study period and multiplying this by the concentration of acid determined by back titration with 0.1 $\mathrm{N} \mathrm{NaOH}$.

Peptides and gastric secretogogues. Synthetic PYY (Peninsula Laboratories, Inc., Belmont, CA) was dissolved in $0.9 \%$ saline containing $0.1 \%$ bovine serum albumin (BSA) and administered intravenously using a peristaltic pump (Harvard Apparatus Co., Inc., The Ealing Corp., S. Natick, MA). Histamine (Sigma Chemical Co., St. Louis, MO) and pentagastrin (Pentavalon, Ayerst Laboratories, New York, NY) were prepared and infused in saline. Bethanechol (Merck, Sharp \& Dohme Div., Merck \& Co., Inc., West Point, PA) was administered in 0.1\% BSA-0.9\% saline.

Statistics. All data are expressed as mean \pm 1 SE. Differences between responses with and without infusion of PYY were determined by a Student's paired two-tailed $t$ test. A $P<0.05$ was determined as significant.

\section{Results}

Effect of PYY on meal-stimulated acid secretion. The acid secretory response to the $15 \%$ liver extract meal plateaued during the last $30 \mathrm{~min}$ of the study hour. The mean acid output $45 \mathrm{~min}$ after introduction of the meal was $6.74 \pm 1.59 \mathrm{mmol} \mathrm{HCl} / 15$ min and $6.90 \pm 1.70 \mathrm{mmol} \mathrm{HCl} / 15 \mathrm{~min}$ at $60 \mathrm{~min}$. PYY $(400$ $\left.\mathrm{pmol} \cdot \mathrm{kg}^{-1} \cdot \mathrm{h}^{-1}\right)$ significantly inhibited $(P<0.05)$ the acid secretory response to the meal 15, 30, and $45 \mathrm{~min}$ after instillation of the meal (Fig. 1). The inhibitory effect of PYY did not achieve statistical significance over the final 15-min period of the study hour. Meal-stimulated acid secretion was maximally inhibited by $35 \pm 6 \%(P<0.05)$.

Effect of PYY on meal-stimulated gastrin release. Serum gastrin responses to the liver extract meal during saline and PYY infusion are shown in Fig. 2. PYY infusion had no significant effect on basal gastrin concentrations. Gastrin responses to the meal were numerically higher during the PYY infusion but this difference did not achieve statistical significance. The mean increment in serum PYY concentrations during infusion of PYY was $429 \pm 18 \mathrm{pM}$.

Effect of PYY on sham feeding-stimulated acid secretion. PYY infusion did not significantly alter the amount of food ingested by the esophageal fistula dogs during the period of sham feeding. Acid output increased significantly following sham feeding. The peak response $(1.85 \pm 0.69 \mathrm{mmol} / 15 \mathrm{~min})$ was observed at $45 \mathrm{~min}$, a secretory rate that was maintained to the end of the study hour. PYY infusion almost completely abolished

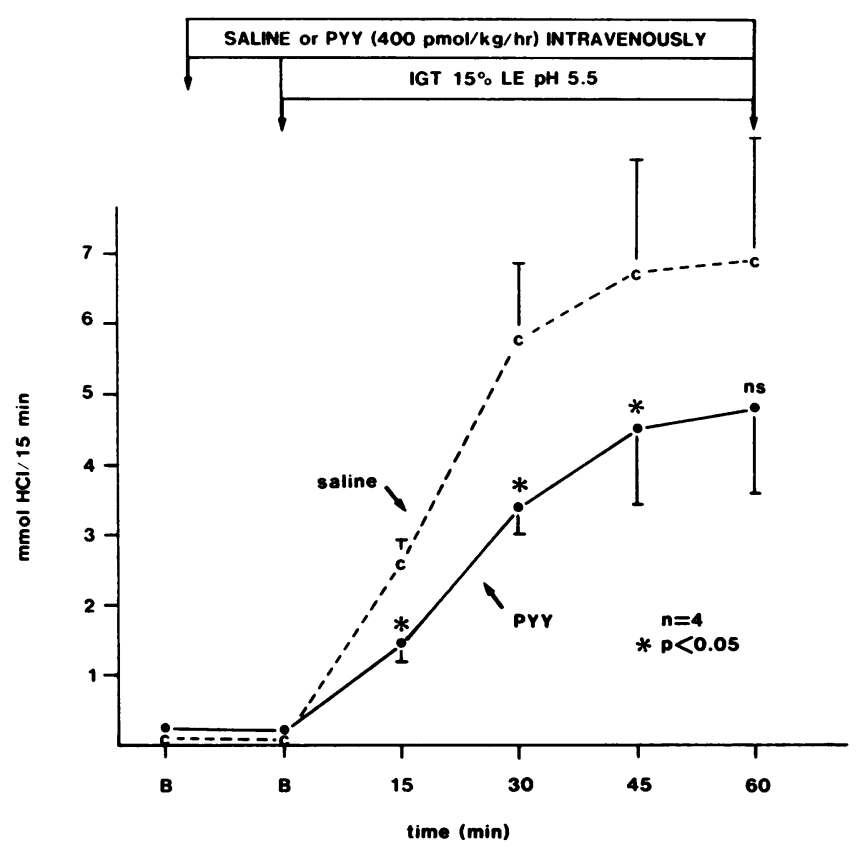

Figure 1. Effects of PYY $\left(400 \mathrm{pmol} \cdot \mathrm{kg}^{-1} \cdot \mathrm{h}^{-1}\right)$ on the acid response to an intragastric meal of $15 \%$ liver extract.

the gastric secretory response to sham feeding (Fig. 3). Maximal inhibition $(P<0.01)$ occurred at $45 \mathrm{~min}$ when the mean acid response was reduced to $0.27 \pm 0.18 \mathrm{mmol} / 15 \mathrm{~min}$. When the maximal inhibition observed in each animal was meaned, acid secretion was reduced by $90 \pm 4 \%$.

Effect of PYY on histamine-, pentagastrin-, and bethanecholstimulated acid secretion. Histamine caused a dose-dependent increase in acid secretion (Fig. 4). Simultaneous infusion of PYY shifted the dose-response curve slightly to the right. However, PYY infusion only resulted in significant inhibition of the acid

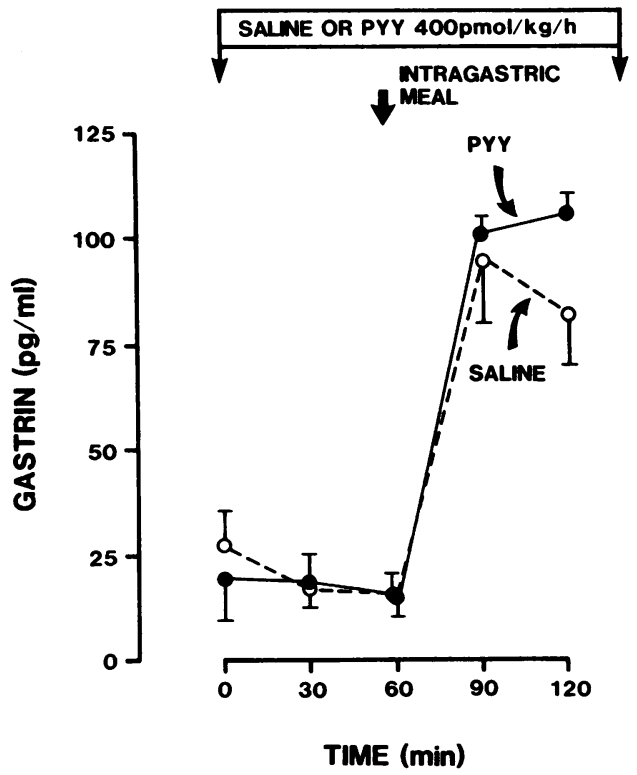

Figure 2. Effects of PYY $\left(400 \mathrm{pmol} \cdot \mathrm{kg}^{-1} \cdot \mathrm{h}^{-1}\right)$ on basal- and mealstimulated gastrin release. 


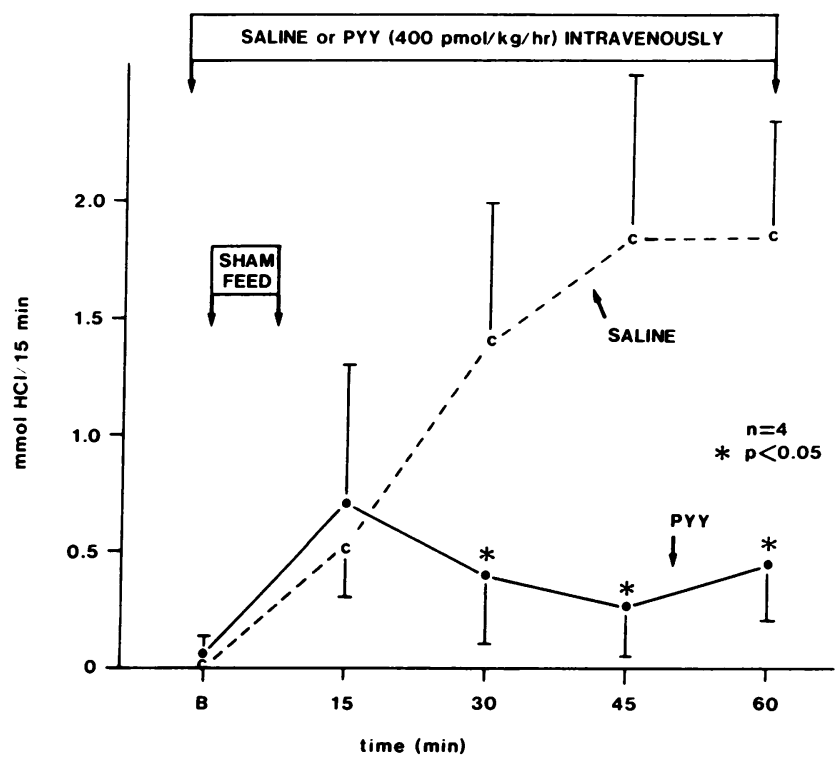

Figure 3. Effects of PYY $\left(400 \mathrm{pmol} \cdot \mathrm{kg}^{-1} \cdot \mathrm{h}^{-1}\right)$ on the acid secretory response to sham feeding.

secretory response to the $40 \mu \mathrm{g} \cdot \mathrm{kg}^{-1} \cdot \mathrm{h}^{-1}$ dose of histamine, reducing this response by $28 \pm 7 \%(P<0.05)$.

After infusion of pentagastrin, gastric acid secretion increased in a dose-dependent fashion (Fig. 5) and peak acid outputs were observed in response to the $8 \mu \mathrm{g} \cdot \mathrm{kg}^{-1} \cdot \mathrm{h}^{-1}$ dose $(9.20 \pm 1.21$ $\mathrm{mmol} / 15 \mathrm{~min})$. Simultaneous infusion of PYY shifted the pentagastrin dose response slightly to the right. However, PYY only significantly $(P<0.05)$ inhibited the acid secretory response to the $4 \mu \mathrm{g} \cdot \mathrm{kg}^{-1} \cdot \mathrm{h}^{-1}$ dose of pentagastrin, decreasing this response a modest $17 \pm 4 \%(P<0.05)$.

Bethanechol also increased gastric acid secretion in a dosedependent fashion and a peak response of $2.79 \pm 0.91 \mathrm{mmol} / 15$

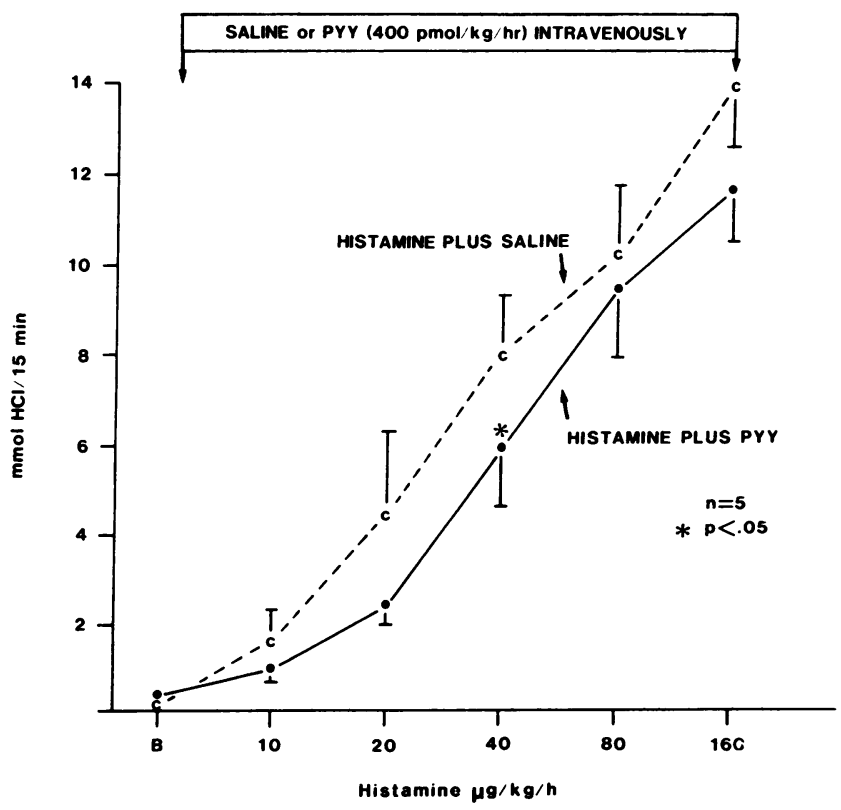

Figure 4. Effects of PYY $\left(400 \mathrm{pmol} \cdot \mathrm{kg}^{-1} \cdot \mathrm{h}^{-1}\right)$ on the acid secretory response to histamine.

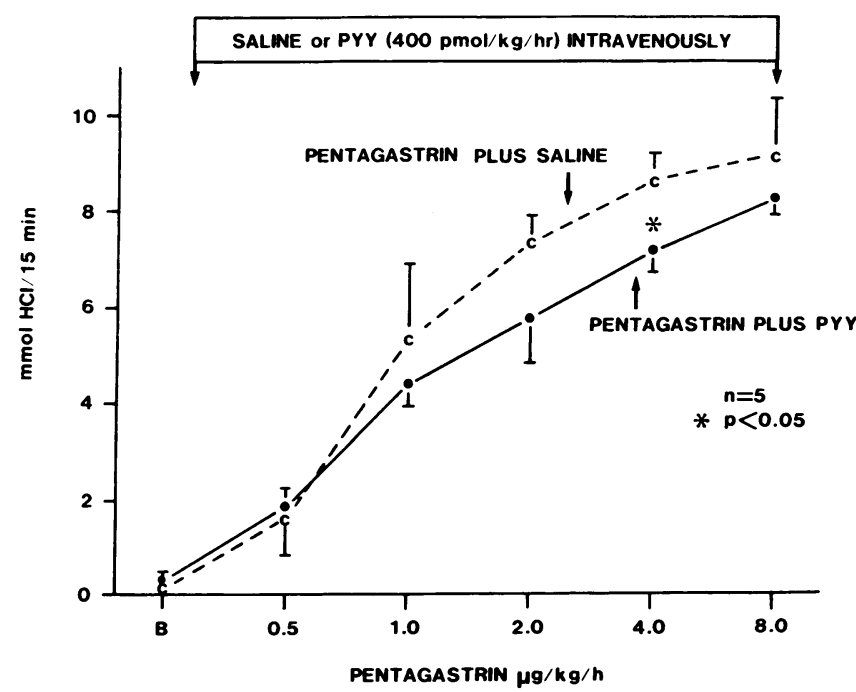

Figure 5. Effects of PYY $\left(400 \mathrm{pmol} \cdot \mathrm{kg}^{-1} \cdot \mathrm{h}^{-1}\right)$ on the acid secretory response to pentagastrin.

min was observed with the $100 \mu \mathrm{g} \cdot \mathrm{kg}^{-1} \cdot \mathrm{h}^{-1}$ dose. PYY did not shift the dose response curve to bethanechol nor did it significantly inhibit bethanechol-stimulated acid secretion at any dose tested (Fig. 6).

Effect of PYY on the acid response to Heidenhain distention. Distention of the Heidenhain pouch resulted in a pressure-dependent increase in acid secretion. $20 \mathrm{~cm}$ of pressure resulted in a mean acid output of $180.0 \pm 7.9 \mu \mathrm{mol} / 30 \mathrm{~min}$ (Fig. 7). The $400 \mathrm{pmol} \cdot \mathrm{kg}^{-1} \cdot \mathrm{h}^{-1}$ dose of PYY only inhibited distentionstimulated acid secretion significantly $(P<0.05)$ when the lowest distention pressure $\left(5 \mathrm{~cm} \mathrm{H}_{2} \mathrm{O}\right)$ was applied. No inhibition of the acid secretory response to distention pressures of 10 and 20 cm was observed.

\section{Discussion}

Peptide YY is a newly discovered member of the pancreatic polypeptide (PP) family that shares $50 \%$ homology with the founding member, PP $(8,9,17)$. Although structurally related, the distribution of each peptide in the body differs markedly.

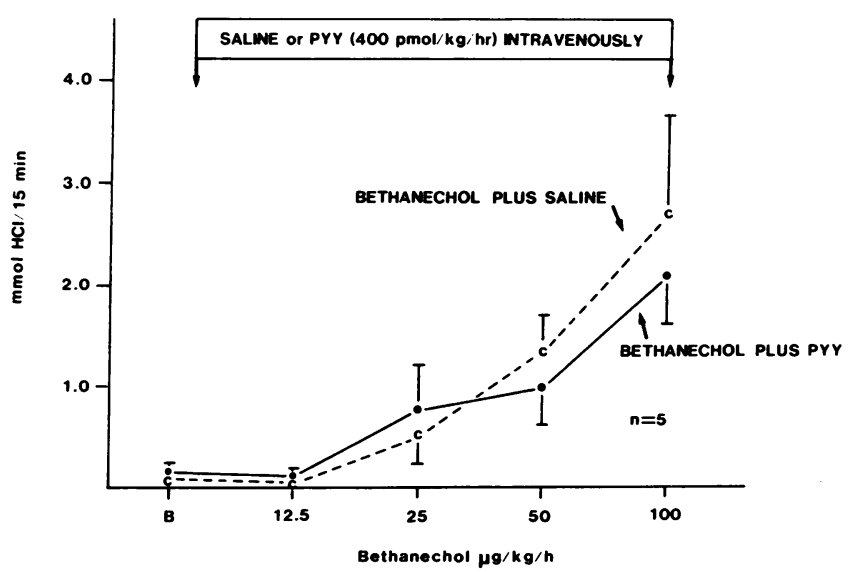

Figure 6. Effects of PYY $\left(400 \mathrm{pmol} \cdot \mathrm{kg}^{-1} \cdot \mathrm{h}^{-1}\right)$ on the acid secretory response to bethanechol. 


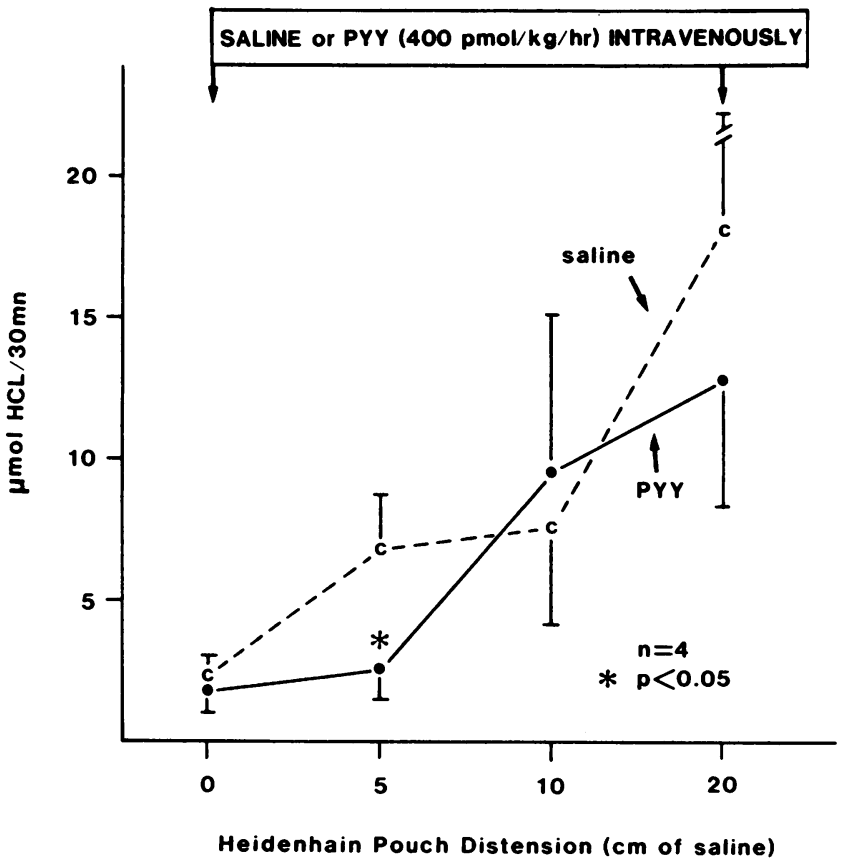

Figure 7. Effects of PYY on the acid secretory response of a Heidenhain pouch to distention.

PP is restricted almost totally to the pancreas (17) while PYY is found in highest concentrations $(9,11,12)$ in the mucosa of the ileum and colon. Although PYY is released into the circulation in response to both ingestion of a meal (12) and intestinal perfusion with oleic acid (10) its physiological role remains to be determined. However, PYY does exhibit the characteristics of an enterogastrone, based on findings that it is released from endocrine-like cells in ileo-colonic mucosa (11) in response to intestinal perfusion with fat (10) and is capable of inhibiting acid secretion (10) and delaying gastric emptying (18).

In the present study we observed that a $400 \mathrm{pmol} \cdot \mathrm{kg}^{-1} \cdot \mathrm{h}^{-1}$ dose of PYY inhibited the acid secretory response to an intragastric meal by approximately one-third. The mean increment in PYY concentrations under these circumstances $(429 \pm 18 \mathrm{pM})$ represents the summation of the response to the liver extract meal and the infusion of exogenous PYY. However, this increase in circulating PYY concentrations is similar to that observed previously (10) after intestinal perfusion with oleic acid $(403 \pm 63$ pM). Although we observed that PYY inhibited meal-stimulated acid secretion by $35 \pm 6 \%$, others $(3,4)$ have observed $90-100 \%$ inhibition of meal-stimulated acid secretion after instillation of $50 \mathrm{~cm}^{3}$ of olive oil into the stomach or colon (4). In addition, meal-stimulated acid secretion is inhibited by as much as $72 \%$ after injection of crude extracts of jejunal and colonic mucosa. Although we had previously (10) observed that a 800 $\mathrm{pmol} \cdot \mathrm{kg}^{-1} \cdot \mathrm{h}^{-1}$ dose of PYY inhibited meal-stimulated acid secretion by $71 \%$, this dose consistently caused retching. As such, this larger dose of PYY may have caused more profound inhibition of acid secretion by inducing nausea. Historically (2) induction of nausea by fat has been a complicating factor in defining the physiological characteristics of enterogastrone. Thus, fat-induced nausea may serve to explain (2) previous reports that enterogastrone is capable of inhibiting histamine-stimulated acid secretion. Nausea due to high fat loads may also explain the great variability in the degree of fat-induced inhibition of acid secretion (ranging from 20 to $100 \%$ ), reported in the literature $(4,19)$.

The early studies of Kosaka and $\operatorname{Lim}(4,20)$ demonstrated that jejunal and colonic extracts were equipotent as inhibitors of gastric function. As PYY predominates in ileo-colonic mucosa, these observations could only be explained by the presence of another enterogastrone or a PYY secretogogue in jejunal mucosa. Several potential enterogastrones, such as cholecystokinin and gastric inhibitory polypeptide (renamed glucose-dependent insulinotropic polypeptide), have already been identified in the small intestine (21). In addition, other candidate enterogastrones (e.g., neurotensin) have been isolated from the ileo-colonic mucosa (21). The concept of multiple enterogastrones even within the ileo-colonic mucosa is suggested by the observation that perfusion of the colon with fat produces greater inhibition of pentagastrin-stimulated acid secretion (5-7) than we observed with PYY. As such, multiple neural and hormonal intermediaries from both large and small bowel probably serve to mediate fatinduced inhibition of acid secretion and their effects may be additive.

The present studies demonstrate that a $400 \mathrm{pmol} \cdot \mathrm{kg}^{-1} \cdot \mathrm{h}^{-1}$ dose of PYY is not a potent inhibitor of acid secretion stimulated by exogenous secretogogues. In contrast, PYY virtually abolished the acid secretory response to sham feeding. Sham feeding is thought to stimulate acid secretion through release of and a potentiated interaction between acetylcholine and gastrin (22). Since PYY had little effect on the acid secretory response to pentagastrin and did not inhibit the gastrin response to a meal, we assume that PYY's inhibitory effect on cephalic phase acid secretion is independent of gastrin. The demonstration that PYY is a potent inhibitor of acid secretion stimulated by sham feeding but has no effect on the response to exogenous bethanechol suggests that PYY inhibits acetylcholine release. However, PYY had minimal effects on acid secretion stimulated by distention of a denervated Heindenhain pouch, a response that may be mediated by release of endogenous acetylcholine induced by stimulation of local stretch receptors (22). If this distension reflex is mediated by acetylcholine then we would assume that PYY does not act on intramural cholinergic fibers or nerve terminals. However, the distention reflex could be mediated by peptinergic nerves (23) and under these circumstances PYY could act at an intramural site.

The concept of an enterogastrone selectively inhibiting psychic secretion can be traced back to Pavlov's time $(2,3)$. These initial observations were extended by the demonstration that intraluminal fat was a potent inhibitor of the acid response to sham feeding in dog (24) and insulin hypoglycemic in man (25). More recently, others (19) have demonstrated that fat-induced inhibition of acid secretion is abolished by proximal vagotomy. The hypothesis that PYY inhibits acid secretion through effects on the vagus would be in keeping with the findings of Suzuki et al. (26) that PYY only inhibited contractile activity in vagally innervated gastric pouches. They suggested that PYY was acting at a preganglionic level. Thus the ability of PYY to inhibit acid secretion and alter gastric motility may both be mediated via the vagus. The recent demonstration of cholecystokinin (27) and opiate (28) receptors on vagal nerve fibers would support the concept that gastrointestinal hormones are capable of modulating vagal tone directly.

One could question the role of PYY as a physiologic enterogastrone based on the fact that the acid secretory response to sham feeding observed in the present study was significantly less 
than the responses observed to intragastric meals or to exogenous secretogogues. However, it has been calculated (23) that cephalicvagal stimulation accounts for $47 \%$ of the acid response to an ingested meal in the first hour and $11 \%$ of the response in the second hour. Cephalic-vagal stimulation potentiates acid secretion during other phases of the meal response. In particular it enhances secretory responses to gastric distention and intraluminal nutrients (23). Because of these potentiating interactions, removal of the cephalic-vagal phase of acid secretory response might have a disproportionate effect on the total secretory response to food. We speculate that PYY also inhibits the gastric phase of acid secretion directly by inhibiting long vago-vagal reflexes that in part mediate this response (23). This would explain PYY's ability to inhibit the acid secretory response to a meal instilled directly into the stomach, a situation in which the cephalic phase is largely bypassed. For these reasons we would predict that PYY would be a more potent inhibitor of the acid secretory response to an ingested meal where both the cephalic and gastric phases are operative.

In summary, we have demonstrated that PYY is a potent inhibitor of cephalic phase acid secretion and suggest that it acts through the vagus by inhibiting acetylcholine release. The present observations call into question the historic criteria used to define hormonal actions. Thus, a biological action that persists after denervation of the target organ is held to be hormonally mediated. Conversely, an action that is abolished by denervation of the target organ is said to be neurally mediated. Our findings with PYY suggest that the actions of some gastrointestinal peptides are so intimately connected with the actions of the autonomic nervous system that they cannot be so easily differentiated.

\section{Acknowledgments}

The authors wish to thank Joan Semasinghe for typing the manuscript and Ray Malendez for skilled technical assistance.

This work was supported by the Veterans Administration and a grant from the National Institutes of Health (NIADDK-AM35247).

\section{References}

1. Ewald, C. A., and J. Boas. 1886. Beitrage zur physiologie und pathologie der verdauung. Virchows Arch. Path. Anat. Physiol. Klin. Med. 104:271-305.

2. Gregory, R. A. 1962. Inhibition of gastric secretion. In Secretory Mechanisms of the Gastro-intestinal Tract. Edward Arnold Ltd., London. 103-133.

3. Feng, T. P., H. C. Hou, and R. K. S. Lim. 1929. On the mechanism of the inhibition of gastric secretion by fat. Chin. J. Physiol. 3:371-380.

4. Kosaka, T., and R. K. S. Lim. 1930. Demonstration of the hormonal agent in fat inhibition of gastric secretion. Proc. Soc. Exp. Biol. Med. 27:890-891.

5. Seal, A. M., and H. T. Debas. 1980. Colonic inhibition of gastric acid secretion in the dog. Gastroenterology. 79:823-827.

6. Jian, R., H. S. Besterman, D. L. Sarson, C. Aymes, J. Hostein, S. R. Bloom, and J. C. Rambaud. 1981. Colonic inhibition of gastric secretion in man. Dig. Dis. Sci. 26:195-201.

7. Kihl, B., A. Rokaeus, S. Rosell, and L. Olbe. 1981. Fat inhibition of gastric acid secretion in man and plasma concentration of neurotensinlike immunoreactivity. Scand. J. Gastroenterol. 16:513-526.

8. Tatemoto, K., and V. Mutt. 1980. Isolation of two novel candidate hormones using a chemical method for finding naturally occurring polypeptides. Nature (Lond.). 285:417-418.

9. Tatemoto, K. 1982. Isolation and characterization of peptide YY (PYY), a candidate gut hormone that inhibits pancreatic exocrine secretion. Proc. Natl. Acad. Sci. USA. 79:2514-2518.

10. Pappas, T. N., H. T. Debas, Y. Goto, and I. L. Taylor. 1985. Peptide YY inhibits meal-stimulated pancreatic and gastric secretion. Am. J. Physiol. 248:G118-G123.

11. Lundberg, J. M., K. Tatemoto, L. Terenius, P. M. Hellstrom, V. Mutt, T. Hokfelt, and B. Hamberger. 1982. Localization of peptide YY (PYY) in gastrointestinal endocrine cells and effects in intestinal blood flow and motility. Proc. Natl. Acad. Sci. USA. 79:4472-4475.

12. Taylor, I. L. 1985. Distribution and release of Peptide YY in dog measured by specific radioimmunoassay. Gastroenterology. 88:731-737.

13. Taylor, I. L., T. E. Solomon, J. H. Walsh, and M. I. Grossman. 1979. Pancreatic polypeptide: metabolism and effect on pancreatic secretion in dogs. Gastroenterology. 76:524-528.

14. Olbe, L. 1959. Esophageal cannula dog, simple mode of preparation for sham feeding experiments. Gastroenterology. 37:460-462.

15. Fordtran, J. S., and J. H. Walsh. 1973. Gastric acid secretion rate and buffer content of the stomach after eating. J. Clin. Invest. 52: 645-657.

16. Taylor, I. L., G. J. Dockray, J. Calam, and R. Walker. 1979. Big and little gastrin responses to food in duodenal ulcer patients and normal subjects. Gut. 20:957-962.

17. Chance, R. E., N. E. Moon, and M. G. Johnson. 1979. Human pancreatic polypeptide (HPP) and bovine pancreatic polypeptide (BPP). In Methods of Hormone Radioimmunoassay. B. M. Jaffe, and H. R. Behrman, editors. Academic Press, New York. 657-674.

18. Allen, J. M., M. L. Fitzpatrick, J. C. Yeats, K. Darcy, T. E. Adrian, and S. R. Bloom. 1984. Effects of Peptide YY and Neuropeptide $\mathrm{Y}$ on gastric emptying in man. Digestion. 30:255-262.

19. Kihl, B., and L. Olbe. 1980. Fat inhibition of gastric acid secretion in duodenal ulcer patients before and after proximal gastric vagotomy. Gut. 21:1056-1061.

20. Kosaka, T., and R. S. K. Lim. 1933. On the mechanism of the inhibition of gastric molility by fat. An inhibitory agent from the intestinal mucosa. Chin. J. Physiol. 7:5-12.

21. Walsh, J. H. 1981. Endocrine cells of the digestive system. In Physiology of the Gastrointestinal Tract. L. R. Johnson, editor. Raven Press, NY. 59-144.

22. Grossman, M. I. 1981. Regulation of gastric acid secretion. In Physiology of the Gastrointestinal Tract. L. R. Johnson, editor. Raven Press, New York. 659-671.

23. Feldman, M. 1983. Gastric Secretion. In Gastrointestinal Disease. M. H. Sleisenger, and J. S. Fordtran, editors. W. B. Saunders Co., Philadelphia. 541-558.

24. Alley, A., D. W. MacKenzie, and D. R. Webster. 1934. Dissociation of the functional properties of the gastric glands under the influence of fat. Amer. J. Dig. Dis. Nutr. 1:333-336.

25. Shay, H., J. Gershon-Cohen, and S. S. Fels. 1939. The role of the upper intestine in the control of gastric secretion; the effect of neutral fat, fatty acids and soaps; the phase of gastric secretion influenced and the relative importance of the psychic and chemical phases. Ann. Intern. Med. 13:294-307.

26. Suzuki, T., M. Nakaya, Z. Itoh, K. Tatemoto, and V. Mutt. 1983. Inhibition of interdigestive contractile activity in the stomach by Peptide YY in Heidenhain pouch dogs. Gastroenterology. 85:114-121.

27. Zarbin, M. A., J. K. Wamsley, R. B. Innis, and M. J. Kuhar. 1981. Cholecystokinin receptors: presence and axonal flow in the rat vagus nerve. Life Sci. 29:697-705.

28. Atweh, S. F., L. C. Murrin, and M. J. Kuhar. 1978. Presynaptic localization of opiate receptors in the vagal and accessory optic systems: an autoradiographic study. Neuropharmacology. 17:65-71. 